\title{
Charles Dickens's Reflection on Race and Empire in The Mystery of Edwin Drood
}

\author{
Tianyue $\mathrm{Li}^{1, \mathrm{a}}$ \\ ${ }^{1}$ School of Foreign Languages, Shenzhen University, Shenzhen, Guangdong 518060, China \\ ${ }^{a}$ Email: litianyueszu@163.com
}

\begin{abstract}
In his early works, especially "The Noble Savage" of 1853, one of his most controversial articles, Charles Dickens expresses rather unpleasant racist views, leading many scholars to consider as a definite racist. However, his last unfinished novel, The Mystery of Edwin Drood, presents a substantial reversion of his past racist stance, indicating his re-consideration of his past opinions about race and Empire. Through analyzing Dickens's intriguing representations of key protagonists and the murder plots in this novel, this paper demonstrates Dickens's challenge of racial stereotypes based on skin color and imperialist arrogance. I contend that this unfinished novel is crucial in the colonial and postcolonial study of Trollope for a comprehensive understanding of Dickens's stance on race and Empire.
\end{abstract}

Keywords: Charles Dickens, The Mystery of Edwin Drood, Race, and Empire

\section{INTRODUCTION}

The Mystery of Edwin Drood (1870), composed by Charles Dickens in his late years, was his last and unfinished novel. Significantly, this detective novel was his only fiction that contains substantial descriptions about racial others. In this murder mystery, the author depicts a homicidal and opium-addicted white man, John Jasper, as the real suspect of the disappearance of young Edwin Drood, his nephew. Intriguingly, though, Dickens also creates several "outsiders" who are racial others as protagonists with positive images, as a contrast to the corrupted white characters. In this sense, Edwin Drood plays an important role in the study of Dickens's stance on race and Empire.

So far, this work has attracted far less scholarly attention than other works of Dickens; nor is its significance in relation to his racial attitude sufficiently noted. A significant number of studies consider Dickens as a determined racist. Patrick Brantlinger, for instance, criticizes Dickens's "genocidal attitudes" in Rule of Darkness (Brantlinger, 1988, 126) [1]. Similarly, Magnet foregrounds Dickens's reactionary figure in Dickens and the Social Order, urging that Dickens's “program for dealing with the Indian mutiny... is to exterminate all the brutes" (Magnet, 1985, 4) [8]. Admittedly, these points of view indeed make sense for Dickens himself did articulate unpleasant and radical views about the racial others in the $1850 \mathrm{~s}$, in particular those written during 1854 and 1857 after the Indian Mutiny. With a son working in Indian then, Dickens was seized by immense anger and anxiety caused by the Indian Mutiny, as a result of which, he composed a few controversial articles, speeches and letters criticizing the inferiority of the Indians. All of these texts seem to be evidence of the author's definite racism. However, we need to admit that these unpalatable expressions are prompt by strong emotions, while within the Victorian culture, emotions were deemed as irrational. Therefore, it is impartial to judge him as a definite racist simply based on his emotional response to Indian uprising in his most sensational moment. For a more comprehensive study of Dickens's racial views, this paper restores The Mystery of Edwin Drood to its due place to analyze his reflection on his earlier view of race and Empire in his late years. I will pay close attention to his representation of characters, in particular, John Jasper and Neville Landless, and his design of the murder plots.

\section{REFLECTION ON THE PREJUDICE OF COLOR}

Admittedly, The Mystery of Edwin Drood could hardly be described as a traditional detective story for it lacks deductive reasoning and the process of gathering evidence to reveal the truth. However, just as detectives must inspect every traces of the suspects in the pursuit of 
the truth, Dickens also depicts his characters in a way in which we readers are capable of predicting his design of murder and thus his attitudes towards the English characters and those of other races. In this sense, this unfinished work undoubtedly helps to reveal Dickens's stance towards racial issues as well as the Empire in his late years.

A good example to the point is Jack Jasper. He is the uncle of Drood and the choirmaster, or the "Lay Clerk" (Dickens, 1985, 19) of the Cathedral [2]. As the story unfolds, we can predict that he is the real murderer of his nephew Drood. However, according to his identity, he should have been the one who receives rave reviews, "enjoying the reputation of having done such wonders with the choir" (Dickens, 19) [2]. In other words, normally Jasper would never be considered as a potential suspect by the local judges in the novel and his contemporary reading public. Nevertheless, with a Godlike perspective, the readers can easily notice that Jasper, heavily addicted to opium, is far from flawless. As Dickens describes at the beginning of the novel, he wakes up "shaking from head to foot" (Dickens, 7) in an opium den, showing no sign of shame [2]. Instead, he "looks with repugnance" (Dickens, 8) at his three companions lying across an unseemly bed just like him, a Chinese, a Lascar and a haggard woman, all of whom succumb to the lure of drugs [2]. Significantly, this scene, and the subsequent description of his several fantasies caused by opium, deconstruct the Orientalization of opium by suggesting that even the so-called "superior" white man can be lured by drugs. Dickens thus exposes the unreasoning stereotype which associates opium with specific "racial others."

However, many scholars such as Donald Hall and Eve Sedgwick consider opium as presented in this novel as a symbol of social descent of the Orient. For instance, Hall regards Jasper's addict for opium as “Orientalized" (Hall, 1994, 177) in Muscular Christianity Embodying the Victorian Age [6]. Similarly, Sedgwick uses the term to define Jasper's addiction to the opium as "in hypnosis through oriental techniques" (Sedgwick, 1985, 182) in her book Between Men English Literature and Male Homosocial [10]. I argue that it is important to note that Jasper's addiction to opium and the consequent illness appeared to be no better than his oriental companions. The only difference lies in the fact that the others are all "outsiders" of the Empire, while Jasper is an influential clergy and pivotal representative of the church in Cloisterham, the setting of this novel. Ironically, Jasper despises these "companions" as inferior to him. Dickens satirizes the ill-based perception of white superiority in creating an irony that an opium addict in disguise, Jasper, however, is reviewed as a respected choirmaster of the city.

In revealing his contempt at this character, Dickens deploys negative descriptions. Although Jasper possesses a "good" voice and figure, which seem to well match his respectable profession, his manner and accommodation are inevitably "sombre" (Dickens, 14) [2]. "Even when the sun shines brilliantly," it seldom touches his piano, music-books and bookshelves, symbolizing the dark nature of this choirmaster of the church (Dickens, 14) [2]. One might feel compelled to see this scene as a clue of his dark impulse to murder his nephew. In addition to his addiction to opium as discussed above, his madly love for both Rosa (the fiancé of his nephew) and his murdering of Edwin demonstrate a kind of "traumatic social descent" (Dolin, 1996, 86) of himself and perhaps also the corruption of the church [4]. The "waning" of the Cathedral, nevertheless, can be noticed from the tone and description of it in the scene in which two clergies talked about Jasper: "The low sun is fiery and yet cold behind the monastery ruin, and the Virginia creeper on the Cathedral wall has showered half its deep-red leaves down on the pavement. (Dickens, 11) [2]." This metaphorical image of the low sun suggests that the glory of the church and empire are waning.

In contrast with his disgust at Jasper, a white villain, Dickens shows admiration for Landless twins, the Ceylon-born brother and sister, at their first appearance: "An unusually handsome lithe young fellow, and an unusually handsome lithe girl; much alike; both very dark, and very rich in color" [2]. The author describes Landless twins' exotic figures with admiration: "Slender, supple, quick of eye and limb; half shy, half defiant; fierce of look" (Dickens, 58) [2]. The images of these two racial others contrast with his unpleasant and racist comments on nonwhite peoples in "The Noble Savage" in which they are described as "mere animals... wretched creatures, very low in the scale and very poorly formed" (Dickens, 1853, 337) [3]. In this sense, Dickens experiences a significant change in his stance on race.

Apart from emphasizing their aesthetically physical figures, Dickens further demonstrates the twins' merits in their characteristics. Even at his first acquittance with Crisparkle, Neville is outspoken and frank, telling Crisparkle not only about his miserable past, but his hidden anger and contempt at his cold and cruel guardian. Furthermore, Neville's trust for his new guardian and his will to become a better person urge him to promise that he "will try to do my[his] part" to control his temper (Dickens, 165) [2]. Throughout the story, Neville strives hard to keep his promise and to undergo the harsh process of "Englishing" (Sedwick, 186), a sort of identity transformation which reflects unreasonable prejudices against his color and race [10]. To demonstrate the suppression imposed by racism, Dickens details the miserable situation of those "racial others" living in the Empire. We hear Neville's confession of "self-hating" (Dolin, 85): "I have been brought up among abject and servile dependants, of an inferior race, and I may easily have contracted some affinity with them" (Dickens, 64) [2] [4]. He suffers from inferiority complex. No wonder 
Neville is so easily irritated when Edwin asserts that he "may know a black common fellow, or a black common boaster...but you [he] are[is] no judge of white men" (Dickens, 79) [2]. Soon after his quarrel with Edwin, Neville reveals his misbehavior to Crisparkle with evident regret and shame. Helena Landless, too, demonstrates a kind of precious courage when facing the misfortune. According to Neville, "nothing in our misery ever subdued her [Helena], though it often cowed me". (Dickens, 64) [2]. As a little girl, Helena never shed a tear even though her horrible stepfather beat her more than one or twice. On the contrary, she "dressed as a boy, and showed the daring of a man" (Dickens, 64) [2].

In addition, Dickens suggests that Neville's untamed and impulsive characteristic is not caused by his "tigerish blood" (Dickens, 64) but arises from his defective education in the past ("I can't paint," is the hasty interruption. Dickens, 75) [2]. Additionally, the author installs the implication that with appropriate guidance, Neville can become knowledgeable and in good control of his temper. For instance, reading offers him comforting peace when he suffers from the white residents" "averted eyes" and avoidance of him by "silently giving me [him] too much room to pass" (Dickens, 194) [2]. After he was mistaken as the highly suspicious suspect of the "murder" case, like some mistreated scholars, Neville "work[s] away" on "good store of books" in his "sparely furnished" and "prisonous" room (Dickens, 193) [2]. Ironically, though, the room is quite bright with "the sunlight shone in at the ugly garret window, which had a penthouse to itself thrust out among the tiles; and on the cracked and smoke-blackened parapet beyond" (Dickens, 193), which is contrary to Jasper's dark and sombre room where "sun...seldom touches" [2]. Dickens might intend this scene as evidence of Neville's successful transformation, proving Dolin's point of view that in this novel, "education and upbringing is therefore integral to the formation of racial characteristics" (Dolin, 87) [4]. Through representing the twins as attractive, Dickens clearly reverses his earlier view about miserable "savage" races.

\section{DICKENS'S SATIRE ON IMPERIAL ARROGANCE}

As "Dickens's condition-of-England-in-the-age-ofempire novel" (Dolin, 85), this novel also discloses his critique of empire and imperialism [4]. Dickens artistically creates a satire on Britain's arrogance through the character Thomas Sapsea, the auctioneer in Cloisterham. Egotistic and arrogant, Sapsea firmly believes that "he would uphold himself against mankind, his weather-glass against weather, and his clock against time" (Dickens, 36) [2]. In the era of arrogant imperialism, Sapsea is elevated by the blind self-confidence to assert that he can conquer nature, time and even mankind. This character reflects the impact of the empire's unprecedented modern technology and growing power have on Britons. As the story unfolds, this businessman urges that "If I have not gone to foreign countries, young man, foreign countries have come to me. They have come to me in the way of business, and I have improved upon my opportunities" (Dickens, 37) [2]. Sapsea perceives other countries merely as Britain's sources of exotic products so that Sapsea's only concern about foreign countries would be on the business perspective, reflecting a sort of prevalent Eurocentrism in nineteenth-century Britain.

Dickens's contempt at the auctioneer shows his disapproval of imperialists' excessive arrogance in the heyday of the Empire. This reflects an emergent structure of feeling in Britain. In 1870, Lord John Russell observed that "[the] time has passed" when Great Britain "could have stood alone" (Faulkner,1994,175) [5]. Witnessing colonies' increasing resistance to the British power, such as the Indian Mutiny and Crimean War, Lord Russell also gained an insight into the fantasy of Eurocentrism. Affected by anxieties surrounding imperialism, Dickens creates this character of Sapsea to criticize Britons" "selfsufficient stupidity and conceit" and their ignorance of subtle but crucial changes across the empire (Dickens, 35) [2].

On the other hand, the novel's heroine Miss Rosa Bud also shows an unconscious superior attitude towards the Orient, by being incredibly ignorant to the east while consuming eastern commodities. Her frequent encounters with the Orient happen in her everyday life. With Edwin Drood, she goes to the Lumps-of-Delight shop to purchase Turkish sweetmeat. However, although Rosa enjoys the Turkish sweetmeat "with great zest" (Dickens, 30), she expresses her dislike for the east, saying that she "hate[s] boilers and things and Arabs, and Turks, and Fellahs" (Dickens, 31) [2]. Miriam O'Kane Mara offers an interesting analysis of this scene, commenting that 'Rosa's fear of the reality of colonialism underscores her fearless consumption of Turkish delight; she refuses to understand anything about the Orient except consumption of its commodities (Moore, 2009, 85) [9]. Rosa indifferently hardly understands the world outside the Empire, displaying an unreasoning sense of superiority. Significantly, her biased knowledge of the Orient is shaped by people surrounding her. For instance, the owner of her Nun's House, Miss Twinkleton, often expresses her opinion about the Orient with disgust: "bore about them, and then you wouldn't ask. Tiresome old burying-grounds! Isises, and Ibises, and Cheopses, and Pharaohses; who cares about them?" (Dickens, 31) [2]. In this sense, Dickens hints at the common ignorance of other cultures in Britain. 


\section{The STRENGTH OF MURDER PLOTS IN REVEALING DICKENS'S LIBERAL VIEWS OF RACE}

The genre of this detective novel has an innate strength in revealing Dickens's liberal views of race. This is because it provides enough clues for his contemporary readers to know that the respectable white choirmaster is the real murderer, rather than the "conspicuously unEnglish" racial others (Dolin, 85) [4]. Among these clues, one of the most evident is Jasper's response to the news that Edwin and Rosa had decided to dissolve affianced relations before Edwin's tragic disappearance. As described, Jasper became "a ghastly figure rise, openmouthed, from the easy chair, and lift its outspread hands towards its head" (Dickens, 176) [2]. Different from his outwardly sorrowful but rather calm appearance at Edwin's "disappearance", Jasper experiences wild emotions due to the late realization of his unnecessary move to end the life of Drood.

Moreover, Jasper's confession about his feelings to Rosa is an even clearer evidence for his crime of murder. In Chapter 19, Dickens spares no efforts to reveal Jasper's true identity of a murderer. Jasper's face is described as "wicked and menacing" and just as this chapter's title suggests, he is undoubtedly the "shadow on the sun-dial" (Dickens, 214) [2]. His mad love for Rosa even compels him to be outspoken about his murder intention. He admits that his "love is mad," which is "so mad" that "might have swept even [Drood] from [Rosa's] side;" whoever Rosa loves, his life "is in [his] hand" (Dickens, 215) [2]. At this point, readers can all easily decide that Jasper, an opium addict and a true villain, murders his nephew because of his insane love for the young man's fiancé. Ironically, initially he escapes the community's skepticism importantly due to his "Englishness" (race and color) and his position in the church. Furthermore, he easily misleads the local people and the jury to treat the innocent though colored Neville as the murderer. Sapsea, for instance, rests "his eyes full on Neville's countenance," reading his "un-English complexion" as an indicator of his violence and criminality (Dickens, 171) [2]. In his lecture delivered at Oxford University, Peter Kemp insightfully remarks that the killer often turns out to be "an overexcitable foreigner" in British crime fictions" [7]. However, Dickens challenges the association between skin color and crime. The readers of Edwin Drood might be quite flabbergasted by the conspicuous conclusion that white and respected Jasper is the one that killed his own nephew. At the same time, given that Neville's miserable sufferings from verbal abuse and alienation will generate sympathy in readers, his skin color would urge people to re-consider their stubborn prejudice against racial others.

\section{CONCLUSION}

Dickens's last novel The Mystery of Edwin Drood suggests that he experienced a radical change in his attitude towards race and empire. Different from his racist outlook as displayed in the early works, this novel discloses Dickens's challenge of racial stereotypes and his satire on the imperial arrogance. In this sense, Edwin Drood is crucial for a comprehensive understanding of Dickens's stance on race and Empire.

\section{REFERENCES}

[1] Brantlinger, P. (1988). Black Swans; or, Botany Bay Eclogues. In Rule of Darkness: British Literature and Imperialism, 1830-1914 (pp.109-133). Cornell University Press.

[2] Dickens, Charles (2002). The Mystery of Edwin Drood. Penguin Books.

[3] Dickens, Charles. "The Noble Savage" Household Words, Volume VII, Magazine No. 168, 11 June $1853,337-33$

[4] Dolin, T. (1996). "Race and the Social Plot in S. West (Ed),The Mystery of Edwin Drood," The Victorians and Race (pp.84-101). Aldershot: Ashgate Publishing Ltd.

[5] Faulkner, D. (1994). The Confidence Man: Empire and the Deconstruction of Muscular Christianity. In The Mystery of Edwin Drood. D. E. Hall (Ed.), Muscular Christianity: Embodying the Victorian Age (175-93). Cambridge: Cambridge UP.

[6] Hall, D. E. (1994). On the Making and Unmasking of Monsters: Christian Socialism, Muscular Christianity, and the Metaphorization of Class Conflict.” D. E. Hall (Ed.), Muscular Christianity: Embodying the Victorian Age (pp.46-65). Cambridge: Cambridge University Press.

[7] Kemp,P. http://open.163.com/special/opencourse/crimefictio n.html

[8] Magnet, M. (1987). Dickens and the social order. University of Pennsylvania Press.

[9] Moore, G. (2009). Turkish Robbers, Lumps of Delight, and the Detritus of Empire: The East Revisited in Dickens's Late Novels. Critical Survey, 21(1), 74-87.

[10] Sedgwick, E. K (1985). Up the postern Stair: Edwin Drood and The Homophobia of Empire. In Between Men: English Literature and Male Homosoical Desire (pp.180-200). New York: Columbia UP. 